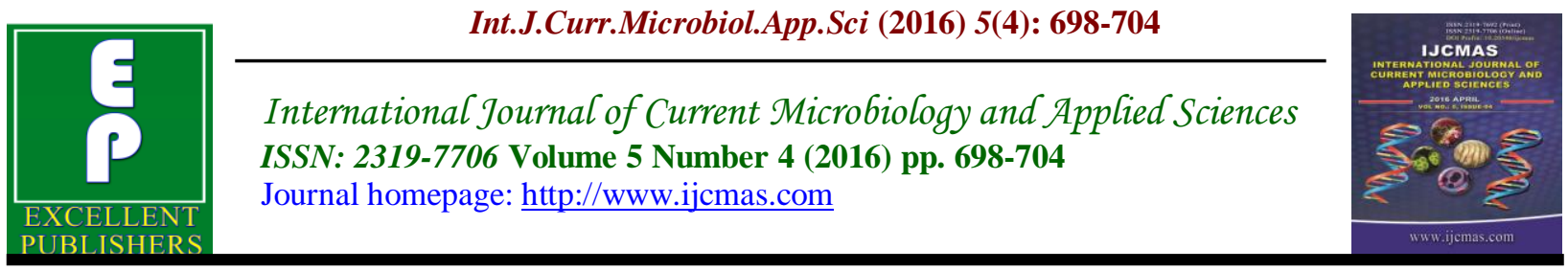

Original Research Article

http://dx.doi.org/10.20546/ijcmas.2016.504.080

\title{
Impact of Mineral Fertilizer Microdosing on the Yield of Sorghum in Adoption Fields of Women Trained in Farmers' Field School of Niako in South Sudan Area of Mali
}

\author{
Diakalia Sogodogo*, Béjamé Coulibaly, Bakary Youba Coulibaly and Karamoko Sacko \\ ${ }^{1}$ Agronome système à l'Institut d'Economie Rurale, Coordinateur national du projet 2009 SHP \\ 003 AGRA Microdose au Mali, Chef de l'Equipe Système de Production et de Gestion des \\ Ressources Naturelles, Station de Recherche Agronomique de Cinzana, Mali BP 214 Segou \\ ${ }^{2}$ Agronome - Gestion Intégrée de la Fertilité des Sols, Chercheur dans l'Equipe Système de, \\ Production et de Gestion des Ressources Naturelles, Station de Recherche Agronomique de \\ Cinzana, IER - Mali \\ ${ }^{3}$ Agronome système, Chercheur dans l'Equipe Système de Production et de Gestion des \\ Ressources Naturelles, Station de Recherche Agronomique de Cinzana, IER - Mali \\ ${ }^{4}$ agronome vulgarisateur, Point focal du projet 2009 SHP 003 AGRA Microdose, ONG European \\ Cooperative for Rural Development (EUCORD) Bamako, Mali \\ *Corresponding author email id: diakalia_sogodogo@yahoo.com
}

\section{A B S T R A C T}

Keywords

Area Yield,

Pilot,

Diffusion,

Micro Dose,

Mineral

Fertilizer

\section{Article Info}

Accepted:

22 March 2016

Available Online:

10 April 2016
In south sudan area of Mali, women grow sorghum in their Fields. In order to improve thé production, those who are trained in farmer field school are applying mineral fertilizer micro dosing in their fields. One study was undertaken in this area to assess the impact of this mineral micro fertilization on sorghum yield. The investigations were done at the level of 213 women in three types of growing sorghum villages: control villages (Sido and Solo), pilot village of Niako and the scaling out villages of Kondo, Banankoro and Nèrèkoro in which woman are applying the technical itinerary learned in farmer field school. The cultivated areas have significantly increased in the pilot and scaling out villages. Sorghum yield has been considerably improved by the application of fertilizer micro dose ( $2 \mathrm{~g}$ of diammonium phosphate/hill during sowing time or 21 first day after sowing when soil is humid). Sorghum yield is better in pilot village that has its input shop and a warrantage ware house indicating that efforts should be put in the technical and financial follow up of women in the diffusion villages.

\section{Introduction}

The decline in fertility of croplands is the basis of food insecurity in households especially the poor peasants are the most numerous in agriculture in the Sudan region of Mali. According to Dixon et al., (2001), the fallow which was the traditional way to restore the fertility of the land has almost disappeared in some places and in others its 
duration was significantly reduced because of demographic pressure. The technical packages to sustainably increase production are not within their reach. From the 1980s, there has been a decline in public funding in agriculture and paralysis of the sector of small producers in developing countries because of the structural adjustment policies of the IMF and the World Bank (Azoulay and Saizal, 1994; FAO, 1995; World Bank, 2007). Many governments in sub-Saharan Africa have made efforts in improving agricultural productivity through the creation of agricultural extension services. But these creations have not fulfilled the expectations of farmers mainly rural women (FAO, 2008).

The development of sub-Saharan agriculture took from that moment an approach for the identification of technical innovation and communication giving more space to the farmers in the development of appropriate strategies for development. The farmer field school is one of these strategies lying in the extension approach of "bottom up" allowing farmers to join the basis for understanding what to achieve in finding appropriate solutions to them development issue. It was piloted in 90 countries and reached 10 to 15 million farmers worldwide (Waddington et al., , 2014).

There are a lot of results on the evaluation of farmer field schools: Togola et al., (2010), FAO (2011), Braun et al., (2006), Feder et al., (2004), and Piyadasa Tripp (2005). There is, against few results on the diffusion of technology from a farmer field school in sub-Saharan Africa (Davis, 2006; Baah, 2007). In this research, we were interested in the fields of adoption training women beneficiaries in a farmer field school. We worked on the following research question: How planted acreage, yield and women's income-they operate in the adoption field?
We posed as research hypothesis that sorghum yields and realized income are better in the fields of women trained in Farmer Field Schools.

\section{Materials and Methods}

The Institute of Rural Economy, the research institution driving the project AGRA (Alliance for the Green Revolution in Africa) Microdose / Mali (2009 SHP 003) developed a partnership with the NGO EUCORD (European Cooperative for Rural Development) executrix activities for site identification, the collaborating farmer organization, resource persons for training, technical, social, logistical work.

\section{Study Area}

The study was conducted in an area where women grow sorghum on the exposed land and rice in the shallows. In the same agroecological zone, three villages batches have been compared:

The control area covering the towns of Solo and Sido where women traditionally produce sorghum on marginal land without addition of mineral fertilizers

The pilot area with the village of Niako that housed the farmer field school, the agricultural input shop and warehouse receipt store. The manager of the shop disseminates information on the use of fertilizers and improved varieties of sorghum in the village.

Disseminating area covering the villages of Kondo, Banankoro and Nèrèkoro where women sorghum fields receiving the mineral fertilizer microdose are in the system of crop rotation and crop rotation of the family farm based cotton (cotton-but-sorghum). In this rotation, but the benefits from the rear effect 
of fertilizer given to cotton. In the distribution area, the women received visits popularizer exchange visit experiences, radio talks and debates

The area receives on average $1164 \mathrm{~mm}$ of rain in 62 days. August is the wettest month with 16 days of rain against 10 or less than 10 days during the other months. The soils are clay loam in the shallows, sandy loam and laterite on dewatered lands. The working hypothesis was that in the same agro-ecological zone, women produce more sorghum and made more money by practicing microdosing of fertilizers they have learned in the farmer field school.

\section{Sampling of Women Producing Sorghum}

A total of 384 women (122 in the driver Niako village, 262 in the broadcast area) practicing microdosing mineral fertilizer in their fields of adoption and 147 women making mineral fertilizer point in their fields was identified in the area by a group of 2 people (one woman and one man). These resource persons had a good knowledge of all households in the project area. A sample of $40 \%$ of these women were randomly drawn in each of the three areas. This amounted to 49 women in the pilot area of Niako that housed the farmer field school, 105 in the broadcasting area and 59 in the control area.

Data were collected by declarative survey of each of the selected women. These data concern the area of sorghum, the yield obtained and then we determined the value / cost of mineral fertilizer microdosing.

\section{General Approach}

To assess the impact of microdosing fertilizer, the approach used is based on a comparative analysis of data collected in different villages in the same agro- ecological zone: area cultivated by women, sorghum yield obtained by each of the women. The ratio Value / Cost (RVC) was used in the economic analysis.

\section{Data Gathering}

A structured questionnaire was administered to each of the women in the sample party. The questionnaire included the identification of the site and the producer, the practice of micro dose of fertilizer, sorghum area that received the micro dose of fertilizer and yield of sorghum field.

Statistical analysis of the variables and the realization of charts and graphs illustration were made using the INSTAT and Excel. The economic evaluation focused on the value / cost (RVC). This report is used in estimating the profitability of a fertilizer and is determined by the formula: $\mathrm{RVC}=$ yield increasing value per hectare in a given time / cost of fertilizer used per hectare.

\section{Results and Discussion}

\section{Area of Adoption Fields}

The difference between the areas sown by women in the villages was highly significant (Table I). Soil fixed location fields on marginal lands in the control area are difficult to work. Therefore cultivated fields are small. The increase in surface area was $87.58 \%$ in the pilot village and $65.82 \%$ in the diffusion zone. After the training in the school field, women have produced sorghum on twice smaller than those of the pilot village areas. They learned to cultivate areas that they can fertilize with mineral fertilizer they buy in cash with their own funds.

\section{Yield Adoption Fields}

Sorghum yield difference between the villages was highly significant (Table I). In 
the control villages, yields are lower because women's fields are located on very poor marginal land in nutrients. Sorghum plants receive only the nutrients released during decomposition of weeds buried for tillage. The pilot villages and dissemination registered respective yield increases of 40.18 $\%$ and $27 \%$. Yields in the broadcast area are $23 \%$ lower than in the pilot village (Table I).

\section{Economic Evaluation}

The sorghum sales price goes from simple to double the harvest period in October to the period of rupture grain stock in attics still called lean period spanning the months of July, August and September. Women sell their crops immediately after harvest to solve needs (clothes and adornments, health and children's education, condiments). On marginal land infertile control villages, the low yields do not allow women to benefit greatly from the sorghum crop. They are still dependent on financial support from their husbands or others. During the harvest period, a franc invested in fertilizer reported 8.6 francs against 17.2 francs during the lean period in the pilot village. While in the broadcast area, a franc invested in fertilizer refers to harvest 4.6 francs against 9.3 during the lean period. Gains spend almost doubled going from the reception area to the pilot area (Table II). They remain the most interesting during the lean period in both zones indicating the existence of a solvent market of grain sorghum that women can enter.

Table.1 Microdosing Impact of Mineral Fertilizers on Crop Area and Yield of Sorghum in the Fields of Adoption of Women in Mali

\begin{tabular}{|c|c|c|c|c|c|c|}
\hline \multirow{3}{*}{ Variables } & \multicolumn{6}{|c|}{ Types of villages } \\
\hline & \multicolumn{2}{|l|}{ Witness } & \multicolumn{2}{|l|}{ Driver } & \multicolumn{2}{|c|}{ Distribution } \\
\hline & Average & ES & Average & ES & Average & ES \\
\hline $\begin{array}{l}\text { Area of } \\
\text { adoption } \\
\text { fields } \mathrm{m}^{2}(* *)\end{array}$ & $947.5(\mathrm{c})$ & 237.5 & $7627(a)$ & 260.4 & 2 771(b) & 177.9 \\
\hline $\begin{array}{l}\text { grain yield } \\
\mathrm{kg} / \mathrm{ha}(* *)\end{array}$ & $981.5(\mathrm{c})$ & 33.05 & 1640 (a) & 36.27 & $1338(b)$ & 24.77 \\
\hline
\end{tabular}

$(* *)$ : highly significant difference at $1 \%$. ES: standard error (.. ) Figures followed by different letters are statistically different

Table.2 Economic Profitability of Mineral Fertilization of Sorghum by Micro Dose in Adoption Women Fields after Training in Farmer Field School

\begin{tabular}{|l|l|l|l|l|l|l|l|}
\hline & $\begin{array}{l}\text { Average } \\
\text { yield } \\
\text { Types of } \\
\text { villages }\end{array}$ & $\begin{array}{l}\text { yield increase } \\
\mathrm{kg} / \mathrm{ha}\end{array}$ & \multicolumn{2}{l|}{$\begin{array}{l}\text { Value of the increase in } \\
\text { FCFA/ha }\end{array}$} & $\begin{array}{l}\text { lost } \\
\text { Fertilizer } \\
\text { FCFA/ha* }\end{array}$ & \multicolumn{2}{l|}{$\begin{array}{l}\text { Relative value / } \\
\text { cost }\end{array}$} \\
\cline { 4 - 8 } & & & $\begin{array}{l}\text { Harvest } \\
90 \mathrm{fcfa} / \mathrm{kg}\end{array}$ & $\begin{array}{l}\text { Welding } \\
180 \mathrm{fcfa} / \mathrm{kg}\end{array}$ & & Harvest & Welding \\
\hline Witness & 981.5 & & & & & \\
\hline Pilot & 1640 & 658.5 & 59265 & 118530 & 6890 & 8.6 & 17.2 \\
\hline Diffusion & 1338 & 356.5 & 32085 & 64170 & 6890 & 4.6 & 9.3 \\
\hline
\end{tabular}

(*): $53 \mathrm{~kg}$ ammonium phosphate / ha at sowing either $2 \mathrm{~g} /$ poquet (130 FCFA le kg) 


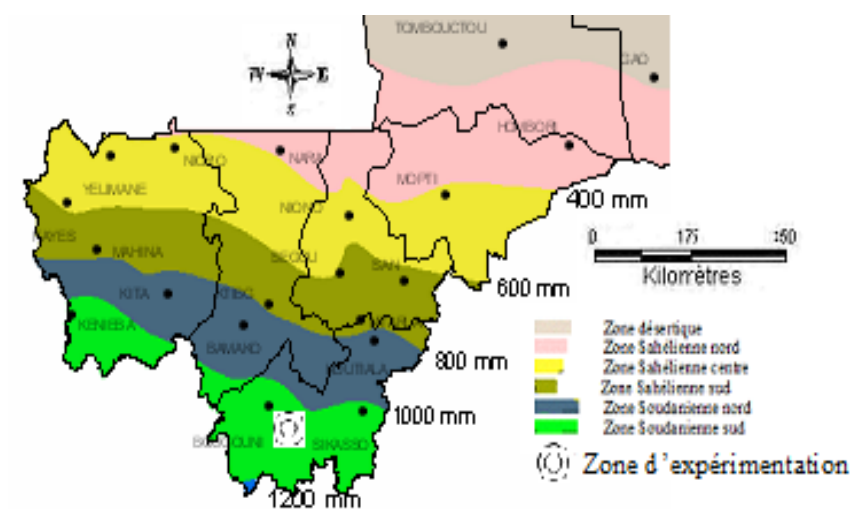

Figure 1 : Zone de l'expérimentation au Mali/Area of experiment in Mali (source LABOSEP de Sotuba/MALI, 2000)

In the 3 areas of the study, women produce sorghum on areas less than one hectare. The land used is managed by customary law which does not grant property rights to women in the land. To exploit agricultural land, the woman is using its right to use time wife of landowners. In the control villages, sorghum yields and women's income remained low because the development of the fields requires more effort than the woman can not provide (tillage, fertilizing, weeding). Women work much more on organic mounds handcrafted. They are often helped by their children or beautiful girls. To make these mounds, we return the land on weeds that will decompose to release nutrients. In the pilot villages and dissemination, the woman uses mineral fertilizer and working on plowed ground or ridged with the plow of the household head. She manages to meet its financial needs. Women in the broadcast area need to be followed up to the total control of the fertilizer microdosing technique: $2 \mathrm{~g}$ of ammonium phosphate / planting hole at planting or 21 days after sowing during a wet period. These results confirm those of Bunyatta et al., (2005) Khatam et al., (2013) who found that the approach of farmer field school improves the knowledge, adoption and dissemination of agricultural technologies. The use of farmer field school as extension method offers farmers a better chance of success in SSA than the method of "Visit Training" (Leeuwis et al., , 1998). In the agricultural development of an area or a country, attention must be paid to the percentage of farmers trained in Farmer Field Schools which is a decisive factor in disseminating information on technologies (Diemuth and Hermann, 2008). Because the key source of information for the peasant farmer is another because it is available and solicitation does not require a high cost (Feder et al., 2004).

In the culture of sorghum, women have few resources (labor, land, money) and their profits are far below those of men despite physical their efforts. In the diffusion of technology, we must consider the type that is a discriminatory factor in access to technology ( Spiller, 2000).

In conclusion, Women produce sorghum in southern Sudan region. But they need technical innovations inexpensive to take advantage of this production activity. The results of the pilot village show that we can give new impetus to the participation of women in agricultural production in developing a partnership including research institutions, finance, communication, agricultural extension, farm input suppliers, exporters, traders and processors cereals. This professional interrelationship between 
institutions will educate women, promote and train women on appropriate technologies. Women may themselves plan their activities, make decisions in the implementation of these rural activities. They can leave the circle of delayed execution of cultural operations, low yields and low incomes.

\section{Acknowledgement}

We sincerely thank the Alliance for a Green Revolution in Africa to finance the project, the staff of the NGO EUCORD, the facilitator of the farmer field school, the village council, residents and members the Benkadi cooperative Niako. Thanks also to all the people contacted in the control villages and dissemination of villages.

\section{References}

Azoulay G. and Saizal R., 1994. Réforme de politique économique en Afrique subsaharienne dans les années 80 et performance du secteur agricole. Etude FAO/ Développement économique et social 129/202 pages.

Baah F., 2007. Meeting the information needs of Ghanaian cocoa farmers: are farmer field schools the answer? Journal of Science and Technology, Vol. 27, No. 3, December 2007

Banque Mondiale, 2007. L'appui de la Banque Mondiale à l'agriculture en Afrique subsaharienne: examen de l'IEG. 101 pages

Braun, J. Jiggins, N. Röling, H. van den Berg and P.Snijders, 2006. A Global Survey and Review of Farmer Field School Experiences. Report prepared for the International Livestock Research Institute (ILRI). Endelea. Wageningen. The Netherlands. 101 p.

Bunyatta D.K., Mureithi J.G., Onyango
C.A., Faustine U. and Ngesa F.U., 2005. Farmer Field School as an Effective Methodology for Disseminating Agricultural Technologies: Up-Scaling of Soil Management Technologies among Small-Scale Farmers in Trans-Nzoia District, Kenya. Proceedings of the 21st Annual Conference San Antonio, TX. P.515-526.

Davis K., 2006. Farmer Field Schools: A Boon or Bust for Extension in Africa? Journal of International Agricultural and Extension Education. Volume 13, Number 1. P/91-97

Diemuth E.P. and Hermann W., 2008. The farmer field school in Senegal: Does Training intensity affect diffusion of information? Journal of international agricultural and extension education. Volume 15, Number 2/P47-60.

Dixon J., Gulliver A., et Gibbon D., 2001. Systèmes d'exploitation agricole et pauvreté. Améliorer les moyens d'existence des agriculteurs dans un monde changeant. FAO, Banque Mondiale. 464 pages.

FAO, 2008. L'accès des femmes à la terre en Afrique de l'Ouest : problématique et pistes de solutions au Sénégal et au Burkina Faso. Mbour, 2 - 4 juillet 2008. www.fao.org/docrep/016/ap532f/ap5 32f.pdf.

FAO, 2011. L'approche 'champs écoles' permet aux petits producteurs du Mali de s'adapter aux changements climatiques/ Journal New agriculturist. Cas d'études publiés pour la journée de l'Agriculture et du développement rural - DurbanAfrique du Sud/3 décembre 2011.

FAO, 1995. Politique d'ajustement structurel et de stabilisation et sécurité alimentaire. WWW.fao.org 
Feder G., Murgai R., and Quizon JB., 2004. The Acquisition and Diffusion of Knowledge: The Case of Pest Management Training in Farmer Field Schools, Indonesia Journal of Agricultural Economics/Volume 55, Number 2/July 2004: 221-243. Agricultural Economics Society)

Khatam A., Muhammad S. and Ashraf I., 2013. Farmers' field school: a strategy for benefiting resource poor farmers in Khyber Pakhtunkhwa, Pakistan. The journal of Animal \& Plant Sciences, 23 (6): 2013. Page 1749-1753

Leeuwis C., Roling N. and Bruin G., 1998. Can the farmer field school replace the $\mathrm{T} \& \mathrm{~V}$ system of extension in subSaharan Africa: some answers from Zanzibar. Proceedings for the 15ème International Symposium of the Association for farming systems research-extension. Pretoria/South Africa/ November $30^{\text {th }}-$ December $4^{\text {th }}, 1998$. P493-497

Spiller, I., 2000 : L'intégration des approches participatives et genre dans les projets de développement rural régional ; le cas de l'ODAI Madagascar. Centre de Formations Supérieures pour le Développement Rural (CFSDR) ; Université Humboldt de Bulint. 1ère édition. Allemagne, 21-26.

Togola A, Agbaka A, Agunbiade TA, Anato F, Chougourou DC, Nwilene FE., 2010. Connaissance paysanne des insectes foreurs de tiges du riz et leurs dégâts dans différentes zones écologiques du Bénin (Afrique de l'Ouest). Cah Agric $2010 ; 19$ : 2626. DOI : 10.1684/agr.2010.0410. Cah Agric, vol. $19 \cdot \mathrm{N}^{\circ} 4 \cdot$ juillet-août 2010

Tripp, R., M. Wijeratne and V. H. Piyadasa., 2005. What should we expect from farmer field schools? A Sri Lanka case study, World Dev, 33(10):17051720.

Waddington H., Snilstveit B., Hombrados J., Vojtkova M., Philips D., Davies P., White H., 2014. Farmer Field Schools for improving Farming Practices and farmer Outcomes: A Systematic Review. Campbell Systematic Reviews:6

\section{How to cite this article:}

Diakalia Sogodogo, Béjamé Coulibaly, Bakary Youba Coulibaly and Karamoko Sacko. 2016. Impact of Mineral Fertilizer Microdosing on the Yield of Sorghum in Adoption Fields of Women Trained in Farmers' Field School of Niako in South Sudan Area of Mali. Int.J.Curr.Microbiol.App.Sci. 5(4): 698-704. doi: http://dx.doi.org/10.20546/ijcmas.2016.504.080 